\title{
LA MEMORIA HISTÓRICA EN EL CORREGIMIENTO DE TUANCHITO (CALI, COLOMBIA): \\ LO QUE RECUERDAN Y OLVIDAN SUS GENTES... Y LO QUE DICE Y NO DICE LA HISTORIA OFICIAL
}

\author{
HISTORICAL MEMORY IN THE \\ SETTLEMENT OF JUANCHITO (CALI, \\ COLOMBIA): WHAT ITS PEOPLE \\ REMEMBER AND FORGET... AND \\ WHAT SAYS AND DOES NOT SAT \\ THE OFFICIAL HISTORY
}

Por:

Olga Lucía Delgadillo Vargas

Profesora Pontificia Universidad Javeriana Cali, Colombia

odelgadillo@javerianacali.edu.co

\author{
Víctor Hugo Valencia Giraldo \\ Profesor Pontificia Universidad Javeriana \\ Cali, Colombia \\ vhvalencia@javerianacali.edu.co
}

Resumen: Este artículo recoge los resultados obtenidos por el proyecto "Juanchito del puente pa'lla" que tuvo como objetivo general "Recuperar la memoria histórica del corregimiento vallecaucano de Juanchito como lugar de encuentro para la actividad festiva y referente turístico de la región”. Tras un diseño de tipo cualitativo basado en el método etnográfico, se adecuaron algunas herramientas a las condiciones de coparticipación que exigía el estudio. Dicha coparticipación era clave para cumplir el propósito de contrastar la historia registrada oficialmente con la historia vivida por los pobladores de este caserío. Se concluye valorando la comparación de las fuentes históricas, en particular, las que registran los discursos oficiales en contraste con los recuerdos oralizados públicamente, pero sin estatus histórico por su inmaterialidad.

Palabras Clave: Memoria, Microhistoria, Identidad, Juanchito. 
Abstract: This article reports the results obtained by the project "Juanchito del Puente pa'lla" that in general terms aimed the "Recovering historical memory of Juanchito a hamlet place on the south of the Cauca Valley as a meeting place for festive activities and tourist reference of region”. After a qualitative design based on the ethnographic method, some tools were adapted to the conditions of co-participation required by the study. This partnership was key to full fill the purpose of contrasting officially recorded history with the history lived by the people of this settlement. We conclude by assessing the comparison of historical sources, in particular those recorded in official speeches in contrast with the publicly oral memories, but without historical status for its immateriality.

Keywords: Memory, Microhistory, Identity, Juanchito.

“A veces vale más la punta de un lápiz que la cabeza de un filósofo", reflexiona don Primitivo Possú ("Don Primo"), un afrocolombiano de 79 años que ha vivido en Juanchito $^{1}$ desde los 9, y quien desde dicha edad trabajó a la orilla del río Cauca extrayendo arena, actividad económica a la que se dedicaban buena parte de los hombres en épocas relacionadas con el auge de la construcción durante la segunda mitad del siglo XX en la vecina ciudad de Cali. Él, como otra treintena de personas, ayudó a reconstruir la historia de esta zona, conocida por las actividades relacionadas con el baile de la música salsa, en el marco del antes citado proyecto.

Y es que Juanchito del puente pa'lla más que tener un claro propósito investigativo, pretendía recuperar información entre los habitantes del corregimiento utilizable luego para la promoción turística, pues Juanchito ha sido una zona usualmente asociada a la historia de la rumba en Cali, siendo los pobladores raizales de este poblado ribereño (a la margen derecha del río Cauca) testigos de la navegación por el río, el tranvía a Cali y luego el tren al Pacífico (en el tramo hasta Buenaventura), entre otros hitos históricos, que permiten entender que no es necesariamente la actividad rumbera la que emparenta a Juanchito con Cali.

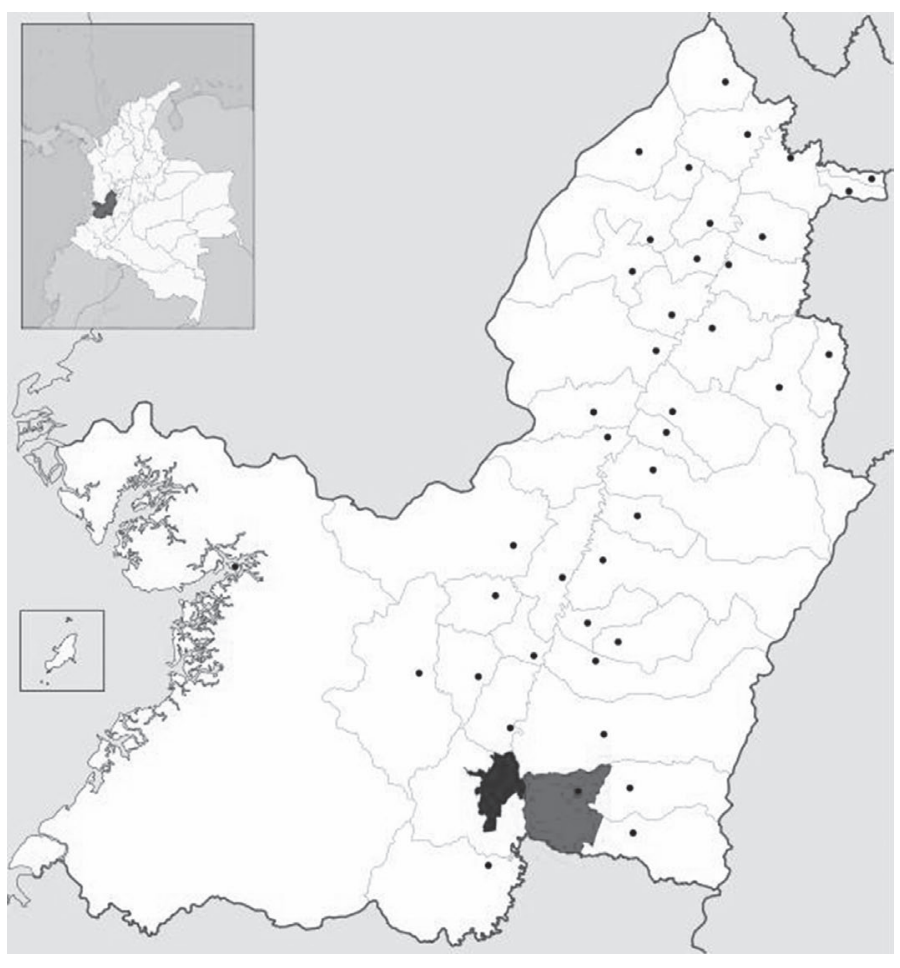

Figura 1. Depto. del Valle del Cauca y Municipio de Candelaria (Disponible en: http://en.wikipedia.org/wiki/File:Colombia_-_Valle_ del_Cauca_-_Candelaria.svg.) [Recuperado: 21 de agosto de 2012] 
La adaptación de las herramientas etnográficas (observaciones participantes y no obstructivas, entrevistas colectivas o individuales -des o semiestructuradas -, y mapeos etnográficos) al contexto, surgió por la necesidad de obtener los datos que permitieran la reconstrucción oral sincrónica, la triangulación y cotejación de información con la historia oficial, y el imperativo proyectual de cumplir con plazos y tiempos que no se avenían a los de aquellos que se invitaban a ser parte de esta experiencia investigativa. De hecho, tras 2 meses iniciales de reuniones fallidas, de encuentros pactados e incumplidos por esa entelequia que los organismos financiadores llaman "la comunidad", se optó por convenir con los pobladores de Juanchito una forma más adecuada, menos rígida, de reunión y de conversación. Fue así como se aprovechó la familiaridad, la amistad, las redes reales de parentesco y vecindad, y los rituales compartidos de quienes se reunían alrededor de la celebración, para invitarlos a compartir un sancocho ${ }^{2}$, una anécdota y hasta un retrato familiar que permitiera registrar las historias "chismeadas" y no sólo la historia escrita (González y González 1999); para así, en convite, desmentir y/ o corregir el registro oficial y acordar entre todos una versión polifónica que dejara satisfechos el recuerdo común de los allí presentes.

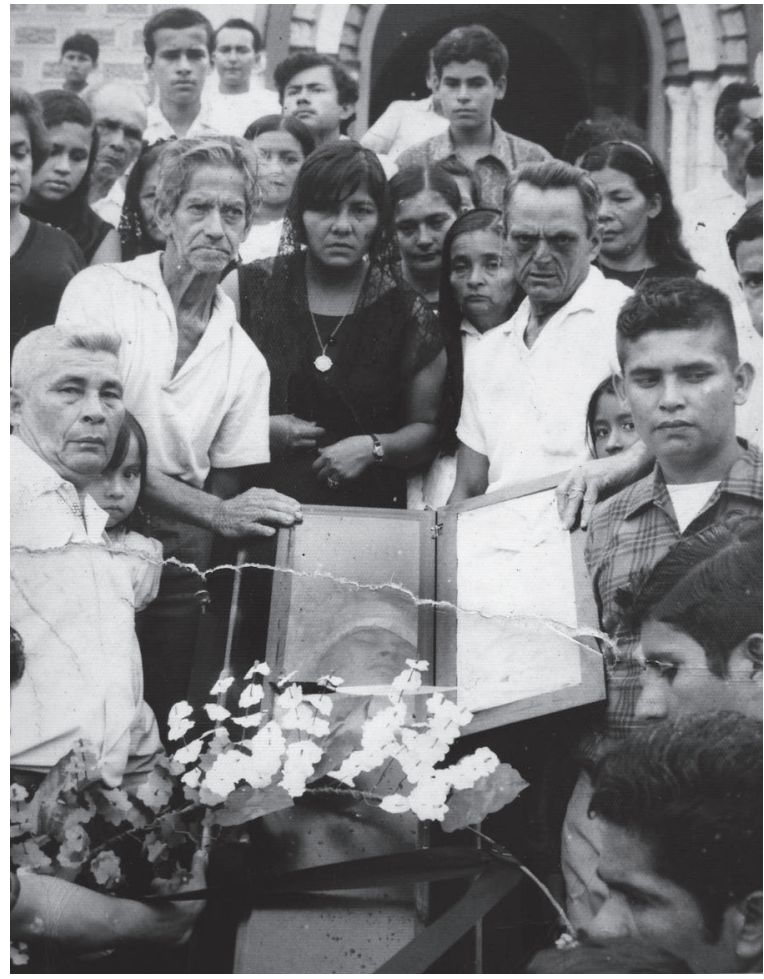

Figura 2. Algunos eventos y ritos extraordinarios de la cotidianidad propia de las gentes de Juanchito (Fuente: Álbum fotográfico de la familia Cortázar: recuperado 06 de junio de 2010).
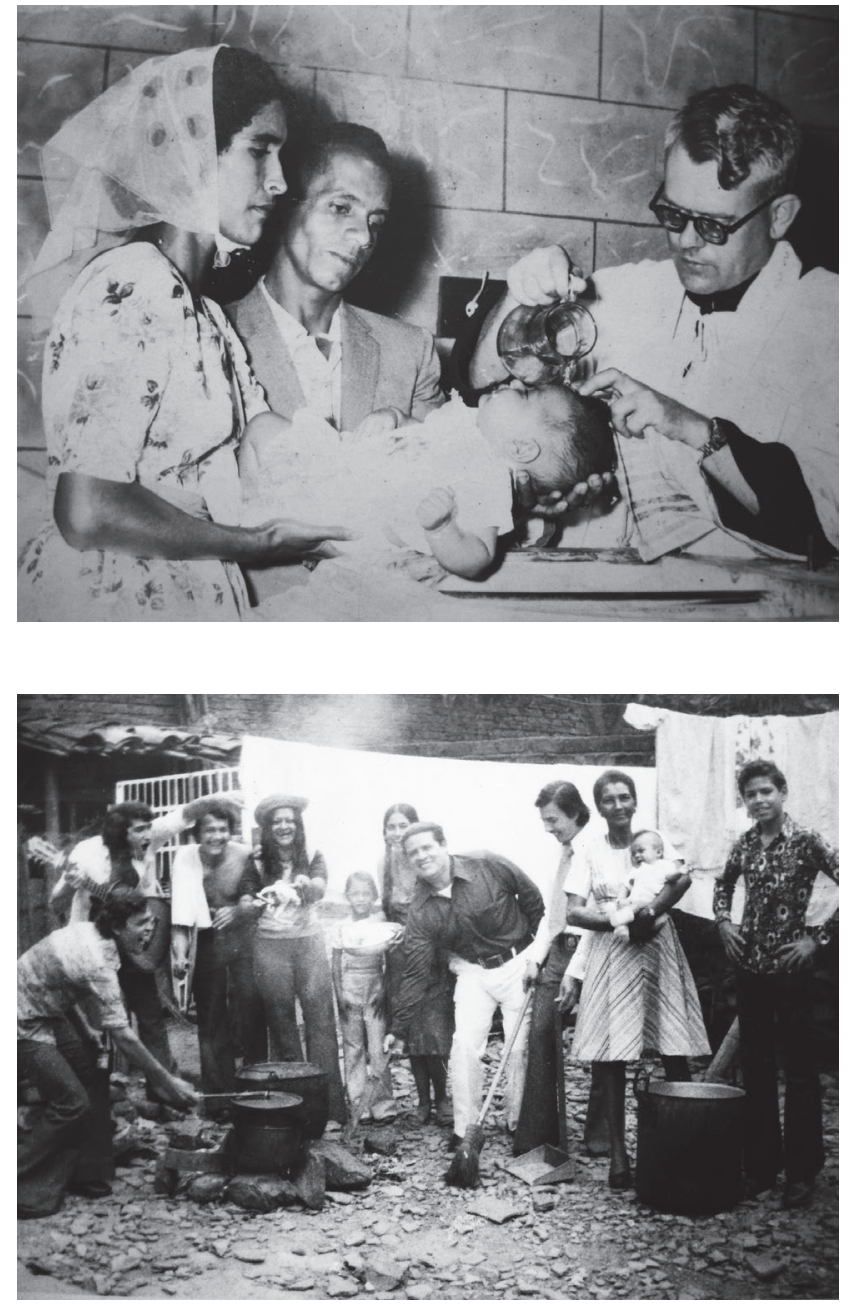
Para ello se recurrió a encuentros festivos ${ }^{3}$ en los que se privilegió la narración oral, el recuerdo vívido alrededor de una fotografía o de una imagen que algunos quisieron compartir de su álbum familiar, o tras la reescritura (sobre un mapa o plano cenital del corregimiento) de las ubicaciones de terrenos, casas de familia, sitios de interés y demás formas de ubicación geográfica que contrastaban el Juanchito recordado por los habitantes raizales con el que hoy viven las nuevas generaciones. Esto daba un lugar protagónico a la cotidianidad pasada y presente de estas personas. De esta manera, mientras el tiempo representado diacrónicamente por distintos acervos documentales formaba un continuum de eventos y hechos sobre Juanchito - desde su fundación hasta estos días -; el tiempo capturado en la imagen fotográfica servía como sinécdoque de lo que fue el siglo XX en Juanchito, según la voz de sus más antiguos pobladores. Al tener la condición historiográfica limitaciones en términos del proceso de negociación multivocal (pues se basa en hechos con los que sólo se puede discutir, no dialogar), se le dio curso a la condición historiofótica, que según dice White es "la representación de la historia y nuestro pensamiento sobre ella en imágenes visuales” (White, 1988). De allí la importancia del álbum familiar: al respecto, Collier (1967) resalta las bondades de la fotografía como herramienta de investigación etnográfica, aduciendo que las comunidades pueden hablar de sí mismas de una manera menos prevenida a través del uso de imágenes fotográficas.

La excusa de reunir para celebrar con la comunidad, en torno a un plato típico de su gastronomía, traía consigo para el equipo investigador unos compromisos logísticos, y para la comunidad unos compromisos de convocatoria que terminaban en la recreación o teatralización de prácticas atávicas cada vez más escasas entre los juanchiteños. Los encuentros y los diálogos allí sostenidos intentaron el contraste criterioso entre los registros oficiales y las versiones que sobre esa historia oficial tenían distintas personas de la comunidad, a fin de validar ${ }^{4} \mathrm{y}$ hacer dialogar a la macrohistoria con la microhistoria (Burke, 1996).

Los datos obtenidos de fuentes secundarias se sistematizaron y consignaron en una línea histórica, obtenida mediante revisión de estudios previos, de escrutinio de prensa escrita ${ }^{5}$ y de archivos históricos de los municipios de Candelaria, Palmira y Cali ${ }^{6}$, así como archivos fotográficos y fílmicos del Archivo Fotográfico Digital de la Gobernación del Valle del Cauca y en la Fundación Patrimonio Fílmico Colombiano. Luego se seleccionaron (mediante un muestreo propositivo por selección limitada) aquellos juanchiteños que aún conservaban la lucidez y la memoria fresca de los hitos históricos del corregimiento, sea porque los vivieron o se los contaron sus mayores. Los informantes-clave escogidos debían cumplir los siguientes criterios de inclusión/exclusión:

- Personas conocedoras de la realidad del corregimiento de Juanchito en los últimos 20 años.

- Personas referidas por la misma comunidad como portadoras de tradición oral significativa.

- 2 personas como mínimo por cada uno de los 5 sectores que integran el corregimiento, por lo menos 1 de ellas debería ser mujer. 
Tanto para las observaciones directas como para la selección de informantes se contó con la ayuda de porteros en cada uno de las 5 veredas (o sectores) que integran Juanchito, lo que permitió que se detectaran actores dinamizadores y de referencia o enlace con la comunidad en cada espacio del Juanchito Rural, y en los sectores del Juanchito Urbano; lo que no pudo ser comprobado por triangulación de fuentes, fue versionado, legitimando con ello la voz de quienes registran hechos usando como única herramienta su memoria.

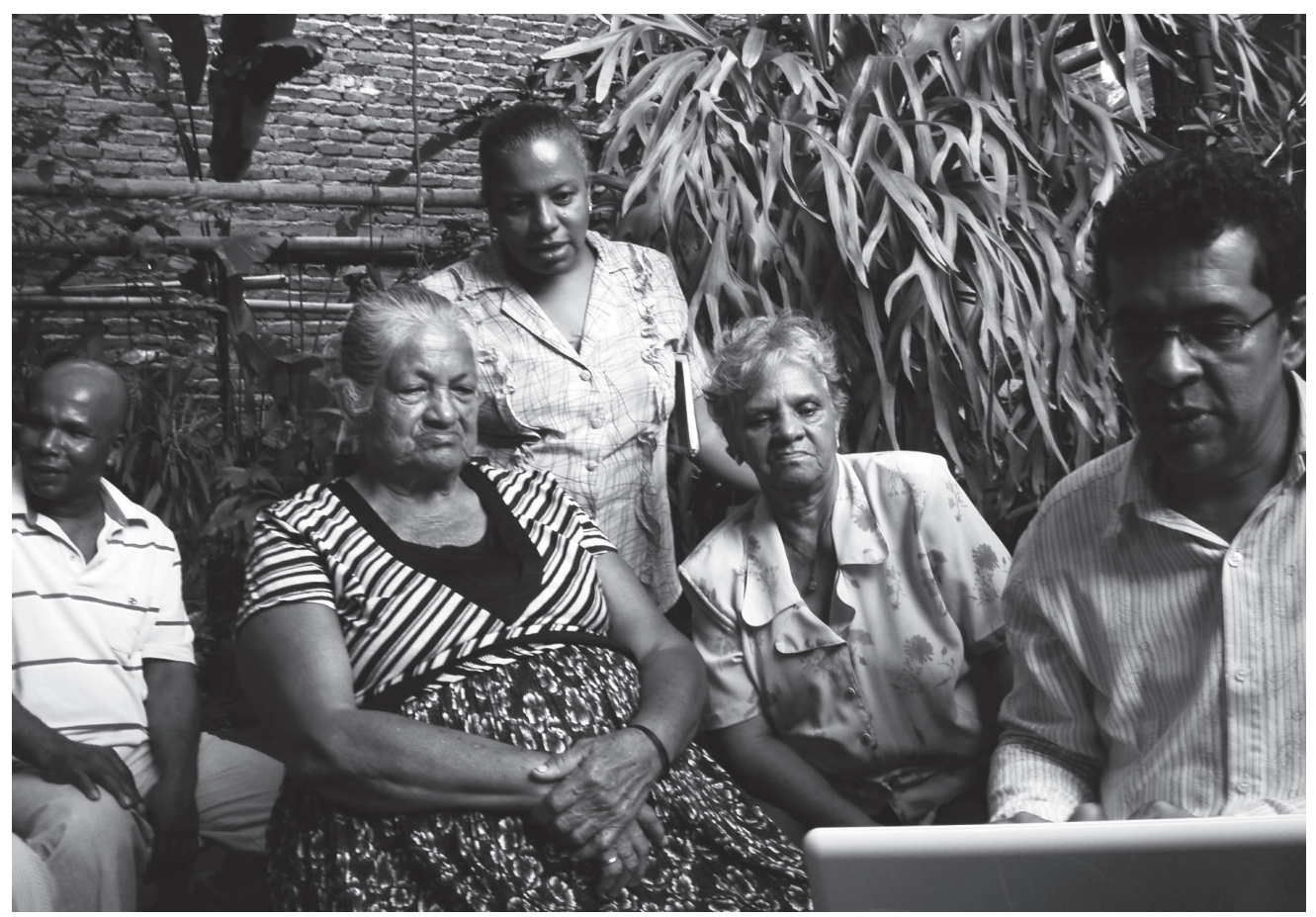

Figura 3. Encuentro Festivo en el Sector Pereyra (17 de mayo de 2010). (Fuente: Elaboración propia).

\section{Resultados}

Burke (2001) afirma que "los grupos dominados se han dado cuenta cada vez más del poder del lenguaje así como de la relación del lenguaje con otras formas de poder”; de allí que durante la ejecución de este proyecto fue inminente la tensión entre la versión oficial que apela a la objetividad histórica, y la "historia desde abajo" (Sharpe en: Burke, 1996), que no relata los hechos de las grandes personalidades, sino los de personas que sin ser protagonistas pueden reconstruir sus experiencias históricas a través de los acontecimientos que vivieron o que les relataron sus mayores. Se intentará mostrar esas tensiones, en particular las surgidas en lo atinente a: A) la ocupación del territorio, B) las actividades económicas, y C) las actividades festivas de los habitantes del corregimiento de Juanchito. Así pues, aparecerán marcados por entretítulos que serán los orientadores temáticos sobre los cuales hablará la historia escrita, la oral y la visual. 


\subsection{La ocupación y domesticación del territorio}

Dicen que Juanchito era un joven negro de baja estatura que a principios de siglo XX ayudaba a cruzar el río en canoa a las personas que estando en una u otra orilla del Cauca debían gritar su nombre con fuerza para que él se acercara a transportarlos. Hay quienes afirman que 'Juanchito' se le dice en el Chocó a un pez parecido al bocachico (Montes Giraldo, 1974), mismo que se pescaba comúnmente en el Cauca. Doña Myriam Ruiz Zapata, habitante del sector Pereyra de Juanchito y perteneciente a una familia con por lo menos 3 generaciones de juanchiteños refiere que los primeros pobladores de Juanchito fueron un blanco español y una esclava liberta, quienes engendraron una de las primeras familias en una zona llamada entonces "El Rincón”. La historia oficial, en cambio, consigna que el oriente de Cali - y hasta el río Cauca - empezó a ocuparse lentamente desde comienzos del siglo XVI, cuando la plebe trabajaba en las haciendas de los pocos españoles que tenían "casa poblada" en Cali. Aprile-Gniset (1991, p.392) dice que el mestizaje triétnico "auspicia una densificación de las tierras en explotación en los alrededores de Cali”, y que la colonización del valle geográfico del río Cauca ocurre durante el siglo XVII, cuando los campesinos españoles pobres, los criollos, y más adelante una creciente masa de "libres" (aborígenes, esclavos, cimarrones, libertos, mulatos y pardos), así como un "dilatado sector de mestizos de todos los colores" fundan pequeños caseríos mestizos que se convierten en el siglo XVIII en "pueblos de libres”, ocasionando en el siglo XIX la sectorización municipal de la región vallecaucana (p.393).

Hacia 1880 nuevos pobladores se ubicaron de a poco en las vegas del río Cauca y se asentaron en la zona. Los actuales vecinos señalan que el corregimiento surgió de un asentamiento formado por esclavos, unos fugados de las haciendas y otros abandonados a su suerte por sus amos, cuando - ya envejecidos - no eran útiles para las largas y exigentes jornadas de trabajo, por lo cual se dispersaban por las orillas del mismo río Cauca (Carabalí 2010).

$\mathrm{Y}$ es que desde finales del siglo XIX existían imaginarios contrapuestos sobre el aprovechamiento de la tierra por los negros contra el uso agroindustrial de este territorio por los blancos y mestizos. Estos imaginarios marcaron el comienzo del siglo XX en el valle geográfico del alto río Cauca. Las acciones políticas y la producción escrita de la época, en particular la de Phanor J. Eder, en su libro Colombia, publicado en 1913, ya planteaba la necesaria intervención desarrollista en este espacio geográfico, pues según él escribía:

Colombia no es un país de opereta, ni un país todo de selvas, fiebres, animales e indios salvajes, donde uno está expuesto a una muerte instantánea. No, es más bien un país normal de carne y hueso, con hogares y familias felices e infelices, y la diaria rutina del trabajo y los negocios. Es un pueblo que cultiva sus plantaciones, que extrae los minerales de las entrañas de la tierra y lava la arena de sus ríos, que tala bosques. Que tiene tiendas...y está seriamente comprometido en el intento de resolver sus problemas políticos, económicos, eclesiásticos, y demás cuestiones nacionales, como lo hacen los británicos, los estadounidenses, los canadienses, los franceses y los alemanes (XIV). (Eder, 2001, p. xiv) 
La Misión Agrícola de Puerto Rico (Misión Chardón) contratada en 1926 por la Secretaría de Industrias para practicar un reconocimiento agropecuario del departamento del Valle del Cauca, mencionó en su informe final que: "Estos terrenos alfombrados por el pará y la yerba guinea y cubiertos de trecho en trecho por los restos de la vegetación original de bosque, enorme, abigarrada y espesa..." (1930, p.126) debían utilizarse para la agroindustria. Era claro que los terrenos anegadizos alrededor del Cauca necesitaban la acción inmediata de la élite burguesa para que creciera en ellos el progreso agroindustrial... de hecho, otro dato recogido por la historiografía regional, refiere cómo la acción de dicha élite cambió trascendentalmente el territorio entre 1864 y 1964 :

Se palpa físicamente allí, sin transición perceptible la profunda transformación que estos cien años han operado en la fisonomía de aquella comarca [el Valle del Cauca] y sus sistemas de vida. A la vegetación salvaje de tupidas y selváticas lianas, poblada de micos y animales indómitos y a las ciénagas insalubres y miasmáticas, incubadoras de endemias tropicales que diezmaban la población, las remplazan hoy dilatados campos sembrados de caña, cruzados por canales de riego y acequias de desagüe, servidos por una completa red de comunicaciones terrestres y laborados por una población de cerca de 2000 familias a la cual se infunde alta noción de la vida y de la dignidad humana, y que disfrutan de trabajo permanente y bien remunerado. (Plazas y Perry Ltda., 1964, p.176)

\subsection{Historia económica $\mathrm{v} / \mathrm{s}$ aprovechamientos productivos locales}

Aunado a lo anterior, todo el desarrollismo promovido por el naciente empresariado vallecaucano - quien capitaliza la condición de nuevo departamento, tras su escisión del Gran Cauca - reclama para sí importantes logros: el comercio por el río en grandes vapores, hacia 1885 según Patiño (1989); la construcción del Ferrocarril del Pacífico - desde Buenaventura, puerto sobre este océano, hasta Juanchito - a comienzos del siglo XX (Mayor Mora, 1999); el crecimiento y ampliación de Cali hacia el oriente desde 1916, gracias al tranvía que conectaba al puerto de Juanchito con el centro de la ciudad (Reyes et al. 2007); entre otros importantes hitos que hicieron de la primera mitad del siglo XX una época caracterizada por la inversión en infraestructura y por la gran actividad productiva en el citado corregimiento (Vásquez et al. 2001).

Pero en el recuerdo de las gentes raizales lo que permanece son otras saudades: algunas de las más mencionadas tienen que ver con la extracción de la arena del Cauca y uno de sus tributarios, el Frayle: la existencia de enormes playones a orillas del río, hacían del trabajo con la arena una práctica productiva por la que comenzaron casi todos los hombres habitantes del corregimiento. El rigor de laborar con la arena hizo 
que alrededor del río se fuesen asentando comunidades negras provenientes de regiones apartadas del pacífico y de todo el suroccidente, según dice don Moisés Hernández en comunicación personal (2010): "[los primeros que llegaban] se instalaban allí y después mandaban una carta y detrás de ellos venía la familia... entonces se fue poblando de la raza negra [que llegaban] a Juanchito en balsas”. Por el río bajaban familias en balsas improvisadas desde el norte del departamento del Cauca, mismas que al llegar a Puerto Mallarino eran desarmadas para la venta de la guadua de la que estaban elaboradas, la cual se usaba en la construcción de casas y edificios.

La única forma asociativa reconocible tanto por la historia oficial como por las gentes de Juanchito fue la Cooperativa de Areneros del Valle, que cerró sus puertas a comienzos de los años '90: muchos de quienes tenían el oficio de la extracción artesanal de arena a la orilla del río y a borde de carretera tuvieron que cerrar sus negocios cuando se comenzó a mecanizar el aprovechamiento del material de arrastre. A decir de "Don Primo", en comunicación personal (Mayo, 2010): “Aquí había un sindicato, una cooperativa. Pero pasa que como en toda parte nosotros somos vendibles... ;Algunos somos vendibles! (...) Ya los ricos vieron que la extracción de la arena era buen negocio, ya pues comenzaron ellos a mecanizarse".

La mecanización - que trajo consigo dragas y malacates eléctricos desde mediados de los ' 80 - acabó con las playas y con el material depositado en el fondo del río. Y es que la cooperativa alcanzó a avizorar las primeras formas organizativas de la comunidad de Juanchito alrededor de lo productivo: hacían asambleas y sesionaban colegiadamente, tenían una Tienda Cooperativa en la que los areneros abastecían a sus familias de los artículos de primera necesidad.

Los habitantes raizales luego de extenuantes faenas salían a tomarse unos tragos en la cantina de su preferencia o a la sombra de los guácimos (Guazuma ulmifolia) que habían a orillas de carretera, todos ellos ya fueron cortados para construir el "Malecón Juanchito"; proyecto que - junto con el de la doble calzada a Candelaria - dicen los habitantes de Juanchito, sólo beneficia a los comerciantes de la rumba. Los hombres lugareños antes se encontraban en la gallera o en el billar, éste último es uno de los pocos espacios de encuentro intergeneracional que quedan en el Juanchito Urbano.

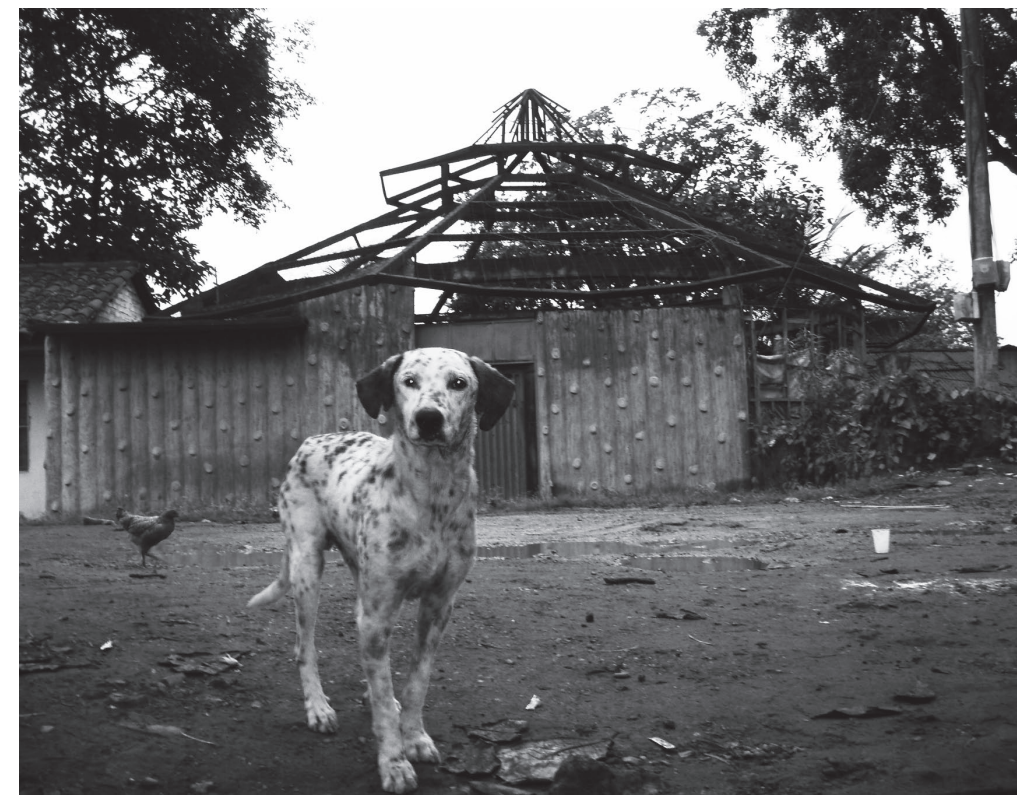

Figura 4. caseta de "Agapito" - sector Caucaseco. (Fuente: elaboración propia). 
En el pasado era habitual que las familias de Juanchito pasaran tardes en los playones del río refrescándose por las altas temperaturas que se presentan casi todo el año: El auge de la construcción en Cali llevó a que todo el balastro y arena depositados en las orillas del Cauca fueran extraídos indiscriminadamente por nuevas empresas que comercializan material de arrastre, y que aun sin licencia ambiental son las proveedoras de las obras civiles que se adelantan en Cali. Las familias que otrora disfrutaban de los playones (que también los protegían de las inundaciones de la temporada lluviosa) ahora sólo pueden fijar sus ojos en el río cuando pasan por el puente que los conecta con Cali.

La pesca sucedía como recreación e ingreso: en aquella época los hombres (areneros, pescadores o simples bañistas) usaban una prenda llamada Pampanilla, que era la simbiosis de lo negro y lo indígena. La versión femenina se llamó Camisola y consistía en una larga bata, que cubría el cuerpo hasta debajo de las rodillas, protegiendo a las

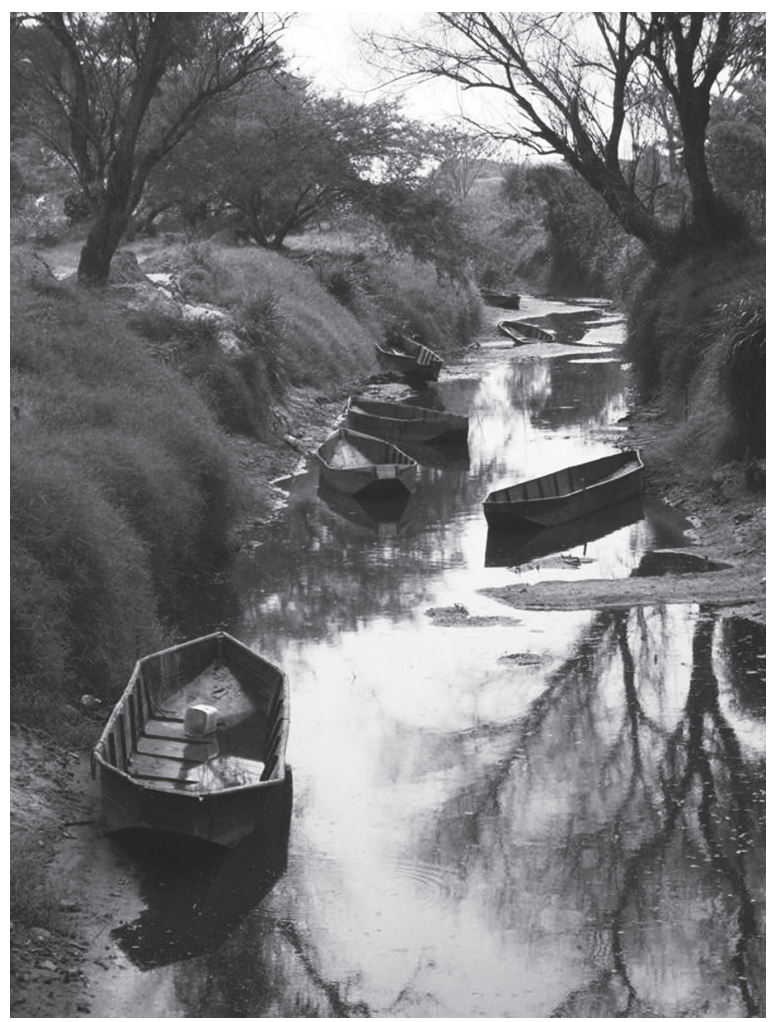

mujeres de las indiscretas miradas de los hombres Dicha prenda era usada durante las faenas de lavado de ropa, pues el agua del Cauca servía para aquello, para limpiar la casa, para espantar el verano, para que la familia la bebiera ("cruda" o "purificada con azufre”) después de haberla guardado en enormes tinajas de barro cocido.

A la extracción de arena del río Frayle se dedicaba buena parte de los hombres adultos de los sectores Caucaseco y El Silencio. Hoy el Frayle es una acequia en la que el agua, altamente contaminada, apenas fluye: la construcción de una bocatoma para proporcionarle riego a las haciendas cañeras de sus alrededores hace que el río ya ni siquiera permita la extracción de arena. En las observaciones realizadas se alcanzó a vislumbrar que los areneros que quedan en el sector de Caucaseco aún se dirigen a las riveras del Frayle e intentan extraer el poco material de arrastre que queda. Cuando el Frayle no deposita arena, ellos pasan el rato jugando a la baraja española.

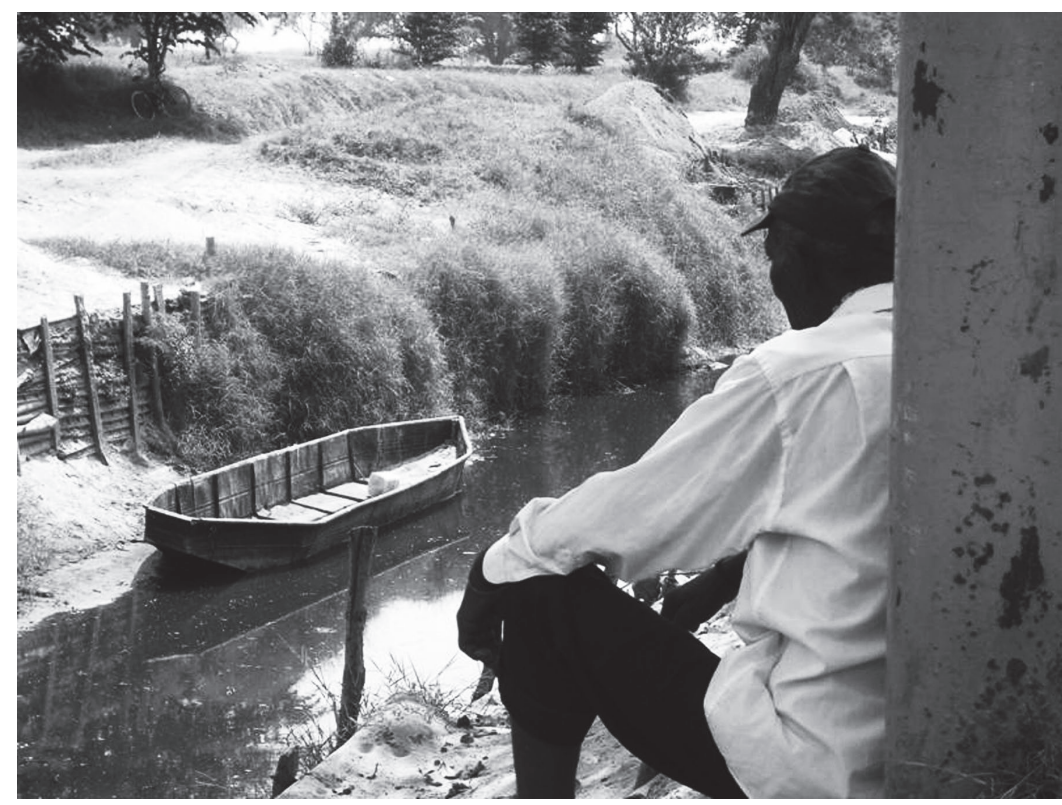

Figura 5. Balsas varadas y arenero observando el lecho seco del río Frayle, a su paso por el sector El Silencio (17 de abril de 2010). (Fuente: Elaboración propia). 
El aprovechamiento del agua de los ríos Cauca y Frayle para el regadío de la caña, o el vertimiento en sus cauces de las aguas servidas tras las faenas agrícolas ha encontrado en tribunas de opinión formalizadas más defensores que detractores: Jaime Lozano en su artículo El paisaje que hemos construido, escrito con ocasión de la celebración del primer centenario de la fundación del Ingenio La Manuelita y publicado en el periódico Occidente, resalta:

El gigantesco trabajo que las últimas dos generaciones de vallecaucanos han realizado manteniendo la figuración de que en estas alturas del tiempo existe aquí el mismo paisaje ecológico del que se vanagloriaban las últimas generaciones del siglo XIX, ha sido una labor tan eficaz en el sentido dicho que a veces permite la paradojal creencia de que aquí simplemente se vive del paisaje. Más no es así. Lo real es la adaptación a las necesidades sociales, a la democratización de la riqueza y a la tecnificación del trabajo que son características del tiempo que vivimos. Es muy poco lo que en la gama de nuestra paleta regional se escapa a los dictados de la economía (...) Realmente, al lado de esas plantaciones nuestras, vigilando los sembrados que parecen solos (...) bulle una inmensa población de trabajadores y técnicos dentro de vastas organizaciones que más tienen de laboratorio que de menaje campestre y se acaloran una serie de cerebros de economistas y empresarios que han logrado trasladar el color del paisaje a la contabilildad. (1964, p.22)

Todo esto posible, según advierte, por el avance del cultivo de la caña de azúcar ${ }^{7}$ sobre la planicie antes inundable que deja a su paso el río Cauca.

Como parece haber sido común en todo el valle geográfico del Cauca, la ganadería fue una actividad productiva anterior al cultivo de la caña de azúcar: las grandes haciendas ganaderas que bordeaban la vieja carretera al primer aeropuerto de la región - Cali Puerto - comenzaron a atraer campesinos del norte del Cauca hasta Puerto Mallarino. Como se ha dicho, el antiguo hato ganadero se convirtió en enormes cañaduzales, que llegan hasta el borde del río, alterando profundamente los ecosistemas, ocasionando severos procesos erosivos que han cambiado el funcionamiento de la cuenca. Sin embargo, la naturaleza indómita, o en otros casos, pastoril y romántica, así como las relaciones de las comunidades asentadas en ambas orillas del Cauca con la naturaleza - y que prevalecieron hasta el siglo XIX - debían ser dominadas o desaparecidas por la vía de la "modernización", lo que permitiría "el abandono en el pasado de las vicisitudes que impidieron el tránsito por las sendas del progreso y de la civilización" (Londoño 2010, p.22). Esta fue la visión promovida por hacendados, comerciantes extranjeros y empresarios de la región ${ }^{8}$. 


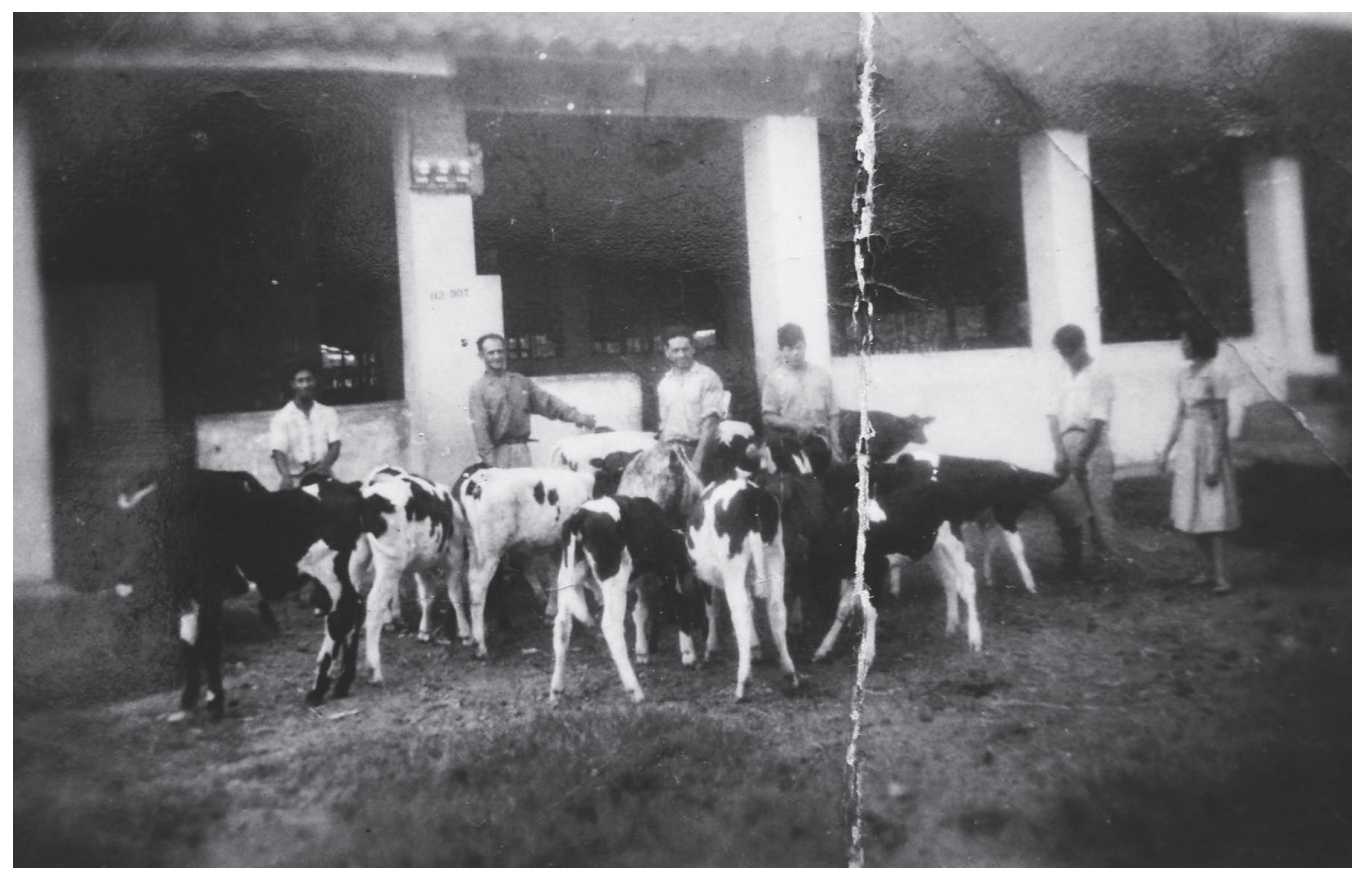

Figura 6. Labores de ganadería en la antigua hacienda "Rancho Chico", de propiedad de Oscar Stemberg. (Fuente: fotografía de propiedad de don Iván Cobo: recuperado 25 de julio de 2010).

La tierra en la parte rural de Juanchito siempre estuvo en manos de familias adineradas, latifundistas tradicionales que han aumentado sus fincas y terrenos en vez de dividirlos o venderlos. Por el contrario, la agricultura del pequeño propietario ha sido primordialmente de huerta, con algunas parcelas de cultivos rotativos (principalmente en la vereda Domingo Largo) y árboles frutales que dan una cierta seguridad alimentaria a la población de la zona hoy conurbada existente entre Cali y Candelaria, sin producir muchos excedentes para la comercialización.

Durante la primera mitad de Siglo XX campesinos provenientes del norte del departamento del Cauca y de las estribaciones de la cordillera central bajaban a un improvisado mercado que hacían los jueves en Puerto Mallarino, plátano, yuca, maíz, cacao, café, entre otros; así mismo - refiere don Paulino Carabalí en comunicación personal (2010) - las familias que tenían cómo sacar sus productos hasta la galería de El Calvario (en Cali), madrugaban para tomar el bus escalera (o "chiva") de las 4:00 am, el mismo en que se arrumaban cajas de mandarinas, mangos y papayas; y en época de cosecha también sacaban bultos de naranjas. Dicha "chiva" pasaba por la antigua carretera que entonces atravesaba el sector de Caucaseco: las primeras familias que habitaron dicho sector hicieron sus casas a orillas de carretera, o del callejón San Diego - que terminaba en el río Cauca - ganándole en muchos casos terreno a sus anteriores patronos.

Este aprovechamiento del territorio responde a un modelo de desarrollo campesino básicamente comunitario (Mejía 1996), una economía de subsistencia que compartía la tierra y el trabajo. Las comunidades campesinas propendían por la integración de sistemas productivos agrosilvopastoriles y por un uso más respetuoso de la tierra y sus recursos; pero, a la luz del modelo de desarrollo agroindustrial que agenciaban los conglomerados 
económicos burgueses del departamento (en asocio con inversionistas foráneos), dicho sistema productivo era propio de "gente perezosa". Históricamente, los campesinos vallecaucanos se opusieron de manera colectiva a la explotación indiscriminada de la tierra y a la presión de grandes terratenientes por "recuperar" sus tierras, defendiendo sus intereses y atacando los de los latifundistas.

Mateo Mina', en su libro Esclavitud y libertad en el valle del río Cauca (2011), consigna cómo sucede el despojo de las tierras a los campesinos de esta zona entre 1950 y 1969. En los primeros años de la década del 50, el uso de nuevas tecnologías (como la fumigación aérea con herbicidas, primero para el cultivo del arroz, y luego para el cultivo de la caña de azúcar) empezaron a afectar a los cultivos de pancoger y a los animales de los campesinos. Las siembras de pancoger remanentes fueron luego remplazadas por pastos. La consecuente ampliación del hato ganadero implicó a su vez el crecimiento de la frontera agrícola; al derribar bosques que precedían las siembras de caña a decir de Mina (2011, pp.145-152). El mismo autor menciona el famoso lema de uno de los terratenientes más destacados del sur del valle geográfico del río Cauca: "El gobierno somos los ricos y nuestras escrituras, las alambradas" (2011, p.121), premisa que al parecer se aplicó hasta desplazar a la mayor parte de los campesinos, y acorralar a los resistentes en zonas marginales cercadas por cultivos de caña.

Ligado a lo anterior, una práctica común entre los habitantes de Juanchito que no tenían suficiente tierra para cultivar, eran las "requisas": consistían en repasar la tierra recién cosechada en busca de alimentos utilizables que en la recolección habían caído al suelo o aún estaban en la plantación ${ }^{10}$. Dos cuestiones contribuyeron a que dicha práctica hoy solo permanezca en el recuerdo de los juanchiteños más ancianos: el monocultivo de caña de azúcar, y un "accidente" que no se les borra de la memoria"

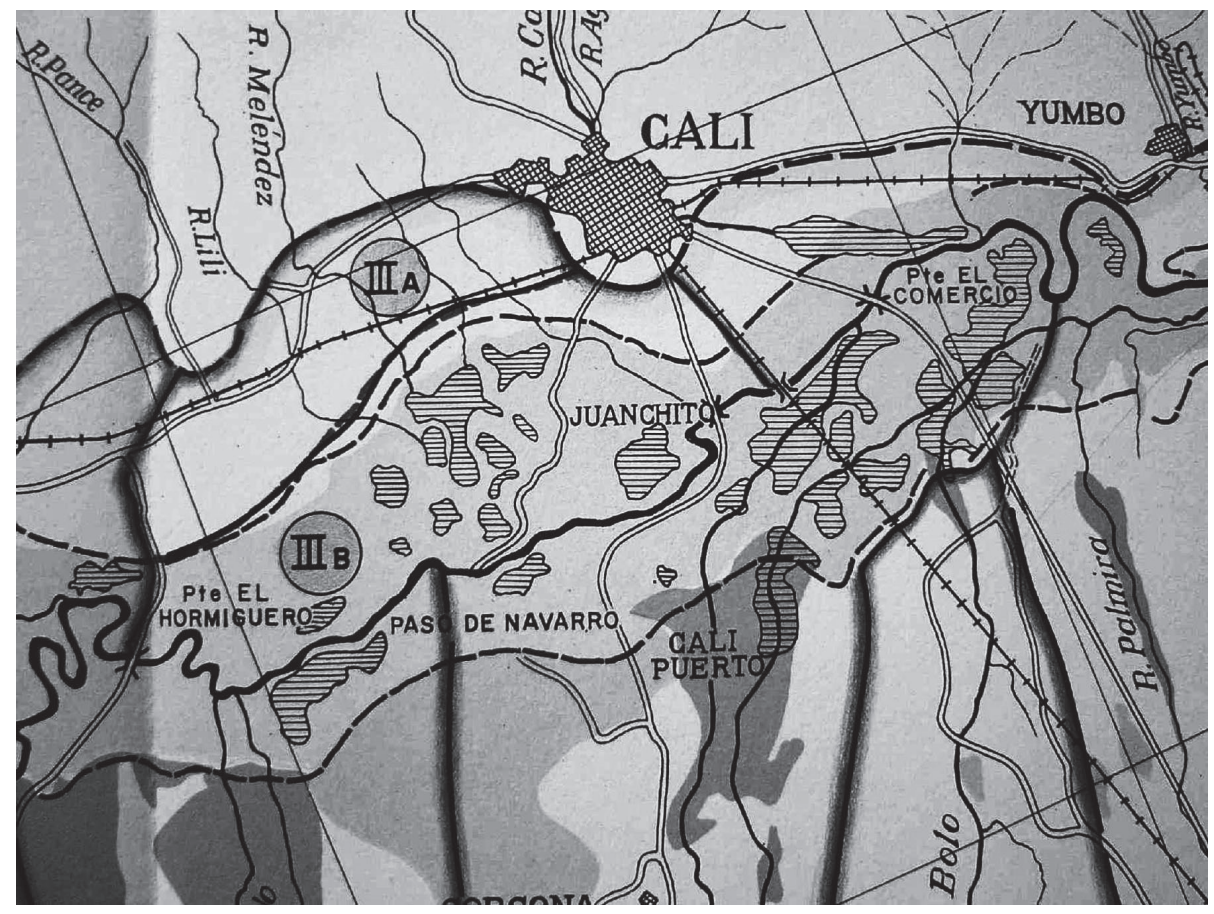

Figura 7. Áreas inundables del río Cauca alrededor de Cali en los años 50. (Fuente: Jiménez et. al. 2004). 
La creación de la CVC, en 1954, marca un hito en la continuación del imaginario de progreso y se constituye en la entidad planificadora, descentralizada y autónoma encargada de promover el desarrollo regional y coordinar la ejecución de proyectos. En 1956 quedan establecidas las orientaciones para la ejecución de proyectos de infraestructura hidroeléctrica y de adecuación de tierras, así como las directrices para dar acompañamiento al desarrollo agropecuario del valle geográfico (CVC 2004, p.128). La ejecución de las obras del Proyecto de Agua Blanca, consistente en diques, canales y planta de bombeo para la protección contra inundaciones del río Cauca, permitió la incorporación a la agricultura de vastas zonas de tierras antes pantanosas e inundables; y habilitó 2000 hectáreas de tierra para la solución de vivienda de gentes pobres (CVC 2004, p.140). El proyecto de Regulación del río Cauca, que permitió la construcción del embalse de la Salvajina, localizado en el norte del departamento del Cauca (el cual se puso en marcha en 1985), y la conformación de 14 zonas para el mejoramiento de tierras, cambiaría para siempre las condiciones biofísicas y paisajísticas de la región, incluyendo las dinámicas culturales propias de poblados rivereños como Juanchito.

\subsection{La actividad festiva}

El Cauca y el Frayle, además de ríos que proporcionaban sustento a los juanchiteños, eran usados entre las décadas de 1950 a 1970 como balnearios y lugares para el esparcimiento dominical de las clases populares de los municipios vecinos, entre los que está Cali. A decir de los habitantes de Juanchito, el florecimiento de la rumba a la orilla del río, en casetas de techo de paja y sin paredes, data de esa época, en la que se comienza a bailar guaracha, son cubano, y posteriormente pachanga y jala-jala. Al mismo tiempo que la rumba aparecen las fritanguerías - de pescado recién atrapado en el $\mathrm{Cauca}^{12}$, y de amasijos y frituras típicas de la región -, y cuando llega la Salsa, a comienzos de los años setenta encuentra el ambiente propicio para el frenesí del vulgo (Jiménez, 2007) hasta que la rumba de Juanchito deja de ser un suceso local y se convierte en industrial ${ }^{13}$. Estos hechos llevaron a Juanchito a una época de esplendor -la más evocada por los actuales habitantes, misma que a su decir comienza en la década de 1940 y llega hasta los años ochenta -, pues había empleo e ingreso tangible y constante.

Quedan en Juanchito muy pocas de las casetas originales: como es la celebración del $1^{\circ}$ de Enero, un evento festivo de gran importancia para los habitantes de Juanchito, es habitualmente un sitio conocido como "El Palo" - ubicado en la vereda El Silencio -, el lugar propicio para la interacción de los habitantes del corregimiento, quienes, sin que nadie "curse" oficialmente invitación, se reúnen a compartir ese día con familias de distintos sectores de Juanchito. Festejan la llegada del nuevo año con trago, baile y comida. Hasta antes de que la CVC aprobara el vertimiento de las aguas servidas de los cañaduzales al río Frayle, era común encontrar a la comunidad el mismo 1de enero en los habituales 'paseos de olla' en algunos de sus "charcos” más apetecidos... y luego a 'rumbear'. 
Las verdades aparentes o "relativas" generadas tanto por la memoria de los pobladores, como por lo registrado historiográficamente, ubican los acentos en acontecimientos significantes según quién los mire: mientras que el baile del bambuco - significativo para los mestizos - ocurría en las casetas, pero de Puerto Mallarino, los negros de Juanchito comienzan el culto por la música grabada (que se escuchaba en victrolas y pianolas, primeros reproductores de acetatos con los que contaron las casetas), y las primeras melodías que llegan en el tren desde Buenaventura son las delTrío Matamoros, de allí su arraigo a ese lugar. A diferencia de otras culturas regionales, en Juanchito no se desarrolla la interpretación musical - la que recurría a instrumentos como la guitarra, el tiple o la bandola... la única vereda de Juanchito que tiene ese tipo de músicos es Domingo Largo: la más mestiza de todas - y de allí que se prefiera la música grabada a las agrupaciones. Este gusto por la música grabada genera hoy en Cali toda una devoción asociada a los encuentros de Melómanos y Coleccionistas (Waxer, 2000).

La ya mencionada industrialización de la rumba - a comienzos de los años ochenta y hasta la fecha - llevó a un alejamiento de la verdadera Juanchito de las dinámicas asociadas a los flujos turísticos que buscan la diversión fácil y esporádica; que (como dice Royman Suarez, vecino del sector conocido como Juanchito Urbano) llegó con Carnavales propios y dejó perico ${ }^{14}$, prostitución, mendicidad y fragmentación social. Hoy Juanchito recibe después de las 2:00 pm a caleños con ganas de seguir la fiesta, pues a partir de esa hora empieza a regir en la ciudad una política de control policivo asociada a la finalización de la jornada de rumba en establecimientos públicos, conocida como "Ley Zanahoria”.

\section{Conclusiones}

La construcción de identidad en una ciudad como Cali no ha tomado en cuenta que el debate sobre la memoria recobrada demanda repensar cómo se relaciona la experiencia con la formación de la propia identidad; lo que implica considerar a la experiencia como una forma de autoinvención y como una práctica social activa (Sturken 1998, p.115). La historiografía, en su afán de combatir cualquier atisbo ideológico, cualquier emocionalidad o sentimiento improcedente (por falto de racionalidad o por traición al proyecto modernizante de las ciencias sociales), ha confundido el respeto a la fuente con la verdad, ha olvidado versionar polifónicamente el pasado, en reemplazo de la acostumbrada monodia atonal... sin contrapunto. Sólo una cómoda armonía que recita lánguida y aburridamente lo ya dicho. Siguiendo únicamente a la historia y a lo 'histórico' de esa perspectiva, se desconocerían las diferencias propias de los encuentros o desencuentros interculturales y se validaría la univocidad dominante, al tiempo que se silencia la voz comunitaria de cualquier relato trascendente; obteniendo como resultado una sociedad que salmodia un solo tipo de historia y cree vivir bajo la égida de una sola identidad. 
Los relatos sobre la historia de Juanchito obtenidos desde la fuente oficial y contrastados con lo recordado trasgeneracionalmente por los habitantes de este poblado revelan la vieja tensión Tradición/ Modernidad: mientras que el registro historiográfico selecciona hitos o acontecimientos que juzga centrales para el funcionamiento de un sistema social, las personas de a pie reconstruyen episodios y eventos significativos para la comunidad y para cada uno de sus individuos. Éstos, a decir de Marco Macarro y Sánchez Medina (2007, p.55), almacenan en su memoria sólo aquellos recuerdos que para ellos tienen significatividad lógica y psicológica. Sabiendo que lo importante para la reproducción social es que las comunidades se vean reflejadas en las historias oficiales (Valcuende del Río 2007, p.22), se puede inferir que la historia sobre Juanchito ha estado dominada por un elitismo cultural que ha despreciado el valor que tiene 'lo cotidiano', en una época en que las identidades se complejizan y se forman nuevos valores (Muñoz 2005, p.298); pues en los relatos construidos desde dicho elitismo se pasan por alto asuntos referidos a la identidad étnica, así como a las identidades de clase y de grupo. Este tema es sin lugar a dudas de enorme interés para los estudios críticos de la cultura, pues es su característica primordial abordar las muchas variables que son constitutivas de la identidad y de la subjetividad.

La memoria, como la historia, es selectiva: los momentos buenos, los malos, los traumáticos y los felices son los que marcan la narración. Los hechos históricos registrados por los historiadores asumen lo documental como un relato diacrónico, cronológico y coherente; mientras que la memoria de los habitantes raizales de Juanchito es totalmente sincrónica, no lineal, rica en detalles y en recuerdos que son intrascendentes para el académico; pero vitales para ellos mismos. Por eso, la revisión y adaptación de las herramientas y los métodos propios del cientista social se convierte en el terreno, antes que en una opción, en un obligación y una demanda de investigación: la fotografía familiar como recurso para el no-olvido o como dispositivo metodológico funciona como la aguja en el tejido que encaja lo social/cultural, con lo personal/territorial... es por ello que en casos como el de Juanchito se deba reclamar una presencia más activa de métodos críticos, en vez de herramientas cientifisistas que combaten las posturas "resistentes" $\mathrm{y}$ las cambian por interpretaciones normativas (Muñoz 2005, p. 303). El enfoque crítico también es deseable en cualquier proceso de diálogo intercultural como el aquí registrado. 


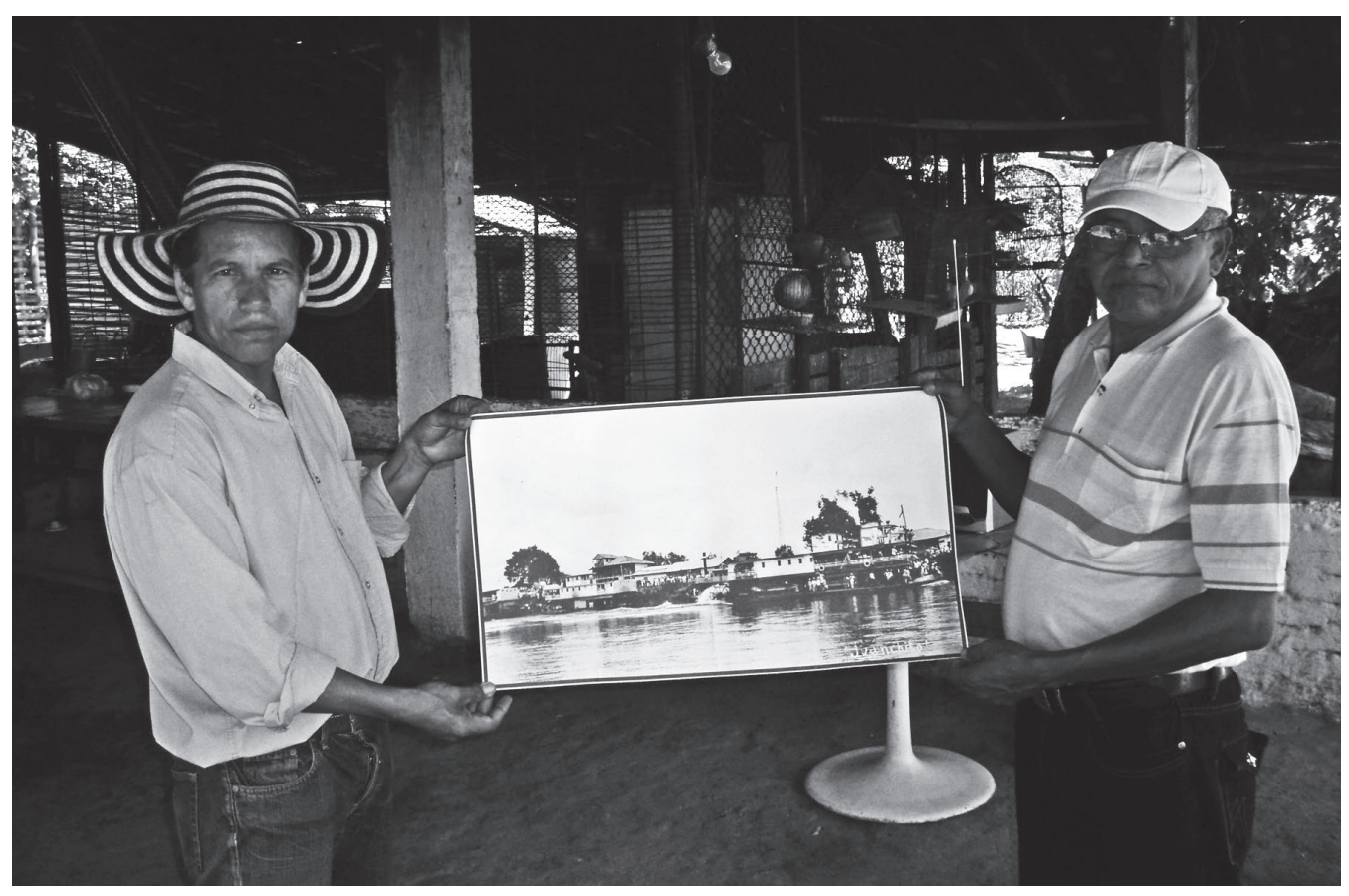

Figura 8. Iván Cobo (izq) y Alberto Pedraza (der.) sostienen una fotografía ampliada del antiguo Puerto Mallarino, en épocas de la navegación por el río Cauca (Fuente: elaboración propia).

Nunca es el mismo territorio el que se ocupa, ni las mismas formas de ocupación las que suceden: mientras que la historiografía narra el territorio del valle geográfico del río Cauca como un lugar que empieza a ser poblado a comienzos del siglo XVI, las personas de Juanchito cuentan su cotidianidad histórica desde referentes vivos, absolutamente necesarios para reconocer su territorio: el samán (Samaneasaman) o la ceiba (Ceiba pentandra) centenaria, el recodo del río, la playa, el puente, la carretera o el callejón ${ }^{15}$. Los mapas etnográficos permitieron devolver la memoria sobre el 'lugar' en el que habitan y donde han transcurrido sus vidas; también sobre las formas de organización en red que tiene la comunidad: si la historiografía mira exclusivamente las prácticas asociativas notorias (principalmente alrededor de lo productivo y lo político), soslayaría los parentescos, las solidaridades y las otras construcciones de orden simbólico que históricamente suceden en el territorio.

Tras la experiencia aquí narrada se puede sugerir que para llevar a cabo un proceso de recuperación de la memoria histórica como el aquí presentado se hacen necesarios los siguientes aspectos adaptables a distintos contextos y épocas: 1) Autodefinición, esto es: la capacidad significante de los hechos y acontecimientos que han marcado de forma original a una comunidad dada, y las identidades resultantes en el proceso. Los pobladores de Juanchito tienen la certeza de ser parte de una comunidad mestiza que ha aportado a la construcción de la vecina ciudad de Cali, tanto porque con esfuerzo sacaron de las playas de su río los materiales con los que se construyó, como porque gracias a Juanchito dicha ciudad lleva más de 40 años haciendo alarde de una de sus más hegemónicas representaciones sociales: la de Capital mundial de la Salsa. 2) Contraste, 
entre elementos como: los “otros significativos" (Taylor 1999), pues nadie se define solo, sino que necesita del reconocimiento ajeno para reafirmar su identidad. La pertenencia a un grupo o comunidad histórica determinada produce un desmarque de los otros grupos y de otros horizontes morales, al tiempo que recíprocamente se afianzan y se afirman las identidades así diferenciadas. En Juanchito, los desmarques se dan frente a la orilla caleña del río Cauca: Puerto Mallarino. 3) Personificación, que consiste en la generación de un núcleo común, un espacio convergente que precise de la cohesión interna, y que supere la comodidad fáctica que se detiene en categorías suficientemente abordadas por las ciencias sociales clásicas, como son etnicidad, género, clase, entre otras. Este núcleo común es - para el caso de Juanchito - el territorio y sus usos culturales... un espacio en donde tienen hundidas sus raíces, y desde donde hoy florecen sus expresiones más esenciales. Finalmente, 4) Acoplamiento: La experiencia humana es entonces el centro del análisis pero necesariamente tendrá que ser contextualizada en el medio ambiente en que se desarrolla. Por supuesto esta visión plantea un reto importante tanto a las ciencias sociales como a las naturales, en tanto plantea el imperativo de recomponer 'la unidad' que debe existir entre la memoria colectiva, las demandas sociales y la base biofísica, y esto pasa por la necesidad imperiosa de conciliar a la sociedad con la naturaleza ${ }^{16}$.

Hoy, buena parte de la rumba en Juanchito se hizo nocturna e industrial, la ocupación de las zonas de reserva del Cauca (sus vegas y riveras) fueron rellenadas por particulares, ocupadas sus orillas por invasores y contaminadas sus aguas por vertimientos domésticos e industriales; lo que impide el libre acceso al río por parte de los pocos juanchiteños que aún anhelan refrescarse del abrasador sol tropical. Es casi seguro que este panorama ayude a sumir en el olvido los recuerdos más vívidos de la celebración en el kiosco y la caseta, del baño y el sancocho... es posible que cuando el Malecón Juanchito sea una realidad, y las industrias culturales asuman el control de la historia social para elaborar un guión que reciten guías turísticos en distintos idiomas, se recreen las prácticas tradicionales como espectáculo circense o como cultura exhibitiva. Por supuesto, en dicho momento, al "googlear" la palabra Juanchito, el algoritmo del buscador (tal vez la "fuente" más consultada al día de hoy) asumirá las historias escritas que acogen las nuevas plataformas digitales como las verdaderas, y las únicas dignas de crédito y reconocimiento.

\section{Notas}

\footnotetext{
${ }^{1}$ Juanchito es un corregimiento del municipio de Candelaria, departamento del Valle del Cauca, Colombia; ubicado al oriente del municipio de Cali, capital del departamento antes mencionado; que de acuerdo con información oficial tiene una población actual de aproximadamente 9.350 habitantes. Fuente:http: / /www.maleconjuanchito.com/html/juanchito.htm [Recuperado: 21-08-2012].

${ }^{2}$ El sancocho es una sopa de gallina típica de Colombia, siendo la versión del sancocho vallecaucano una de las más apreciadas de la gastronomía nacional.

${ }^{3}$ La modalidad de entrevista colectiva llamada sugerentemente Encuentro Festivo, de los cuales se realizaron 5 en total, buscó adaptar los espacios de reunión (temporales y geográficos) no a la conveniencia de los investigadores, sino a la posibilidad del encuentro social entre los habitantes de los distintos sectores; pues muchos de ellos (a pesar de vivir en un territorio relativamente cercano y ser fundadores del corregimiento, por lo que se conocían desde mucho tiempo atrás) llevaban años sin verse y sin hablar de sus vidas.
} 
${ }^{4}$ Dicha validación se hizo por triangulación y por saturación.

${ }^{5}$ En particular, aquella que registraba dos acontecimientos de gran significación para la comunidad: los Carnavales de Juanchito (sistematizados mediante fichas, con un total de 65 apariciones mediáticas: 56 del periódico El País, 8 del periódico Occidente, y 1 en el periódico Q’Hubo); y las inundaciones del río Cauca y Fraile que con antelación afectaron algún sector del corregimiento (información recabada de los periódicos más como contexto, que como hecho premeditadamente categorizado por los investigadores).

${ }^{6}$ Mismos a los cuales está adscrito física y/o simbólicamente el corregimiento de Juanchito.

${ }^{7}$ Según las palabras del mismo autor: "Alrededor de estos titanes [los ingenios azucareros] todo era distancia, todo era difícil y la mayor parte de la planicie se desperdiciaba bajo la canícula del trópico".

${ }^{8}$ Los principales exponentes de esta visión fueron Ciro Molina Garcés (1891-1953) y Carlos Durán Castro (1897-1993), representativos personajes de la élite vallecaucana y empresarios quienes ostentaron altos cargos públicos nacionales y departamentales.

${ }^{9}$ Seudónimo utilizado por el médico y sociólogo Michael Taussig y la arquitecta Anna Rubbo, ambos australianos). El libro original fue publicado en 1975 por la Fundación "Rosca de Investigación y Acción Social”, y reeditado por la Universidad de los Andes y el Observatorio de discriminación racial en 2011.

10 "Cuando se cosechaba, porque eso se cosechaba a mano, luego venía una máquina y lo trillaba, después que la máquina lo trillaba la gente entraba a requisar lo que quedaba por ahí, vainitas y pepitas. Hacían hasta la arroba para ir a vender... o para comer uno en la casa porque uno usaba mucho ese frijolito pa' la casa. Se cultivaba mucho fríjol, la soya... es que ahora comenzaron a meterle mucha soya a eso. Últimamente ni soya, ya no es sino millo. Porque todo eso se lo robaba la gente: el maíz, el fríjol, todo eso se lo roba la gente" (Entrevista a don Salomón Cabrera, Abril 18 de 2010).

${ }^{11}$ Alguna vez, refiere el mismo don Salomón (18/04/2010), estando él con un grupo de amigos adelantando una "requisa" en un predio del señor Alfonso Nagano; éste sacó un arma y disparó contra la muchachada allí reunida, hiriendo de muerte a uno de ellos.

${ }^{12}$ Era tan importante el pescado para la comunidad de Juanchito que una de las cuestiones recreativas y turísticas que han distinguido históricamente la zona - la venta de fritanga - pasaba por el ofrecimiento a orilla de carretera de pescado frito con patacón. Hoy las fritangueras que vendían lo que el río Cauca y sus orillas producían no están ya más.

${ }^{13}$ La historiografía y los archivos municipales sitúan la aparición de las primeras casetas alrededor del mercado de Puerto Mallarino, entre las décadas de 1890 y 1910 (Valencia Llano 1992). Antiguas infraestructuras de bodegaje y talleres se convierten en kioskos para los pasajeros que esperaban el vapor que los llevaría por el río Cauca a sus destinos al sur o norte de Juanchito; haciendo más agradable su espera escuchando y a veces bailando bambucos y música colombiana.

${ }^{14}$ Perico se le dice en Cali popularmente a la cocaína. Los carnavales de Juanchito - que comenzaron a hacerse en los años ' 80 auspiciados por Larry Landa, quien después muere en una cárcel estadounidense condenado por narcotráfico - inauguran la etapa que aquí se ha llamado de industrialización de la Rumba, trayendo consigo todas las consecuencias propias de la narcoeconomía que se aposentó desde entonces en la región.

${ }^{15}$ Estos lugares están cargados de sentido para la gente pues actúan como medio/modo/espacio de comunicación y de integración generacional y no solamente como referente geográfico, (Valencia 2009).Los relatos de la historiografía convencional siguen ubicados en un vacío material, sin referencias físicas ni biológicas, y sin tomar como base las leyes de la naturaleza que hacen posibles o imposibles determinadas prácticas sociales (González de Molina 2009, p.220).

${ }^{16}$ La historia ambiental se fundamenta en el principio de coevolución social y ecológica, ya que entiende la relación entre la sociedad y la naturaleza de manera integrada; esto es, que considera al sistema social como una parte más de los sistemas naturales (González de Molina 2009, p.222). 


\section{Referencias}

Aprile-Gniset, J. (compil.) (1991). La Ciudad Colombiana. Bogotá: Fondo de Promoción de la Cultura del Banco Popular Ecoe Ediciones.

Arroyo, J. H. (2002). Historia de las Prácticas Empresariales en el Valle del Cauca. Cali: Universidad del Valle. Burke, P. (Ed.). (1996). Formas de Hacer Historia. Madrid: Alianza Editorial.

Burke, P. (2001). Hablar y Callar: Funciones Sociales del Lenguaje a Través de la Historia. Madrid, España: Gedisa,

Burke, P. (2005). Visto y no visto: el uso de la imagen como documento histórico. Primera edición. Barcelona: Crítica - Biblioteca de Bolsillo.

Carabalí, P. Entrevista del 1 de septiembre de 2010.

Castro, M. V. (1996). Reseña geográfica e histórica del río Cauca y la navegación a vapor: 1884-1930. (Tesis de Licenciatura en Historia) Facultad de Humanidades, Universidad del Valle, Cali.

Collier, J. J. \& Collier, M. (1967). Visual Antropology: Photography as a Research Method. Albuquerque: University of New Mexico Press.

Corporación Autónoma Regional del Valle del Cauca - CVC. (2004). Génesis y Desarrollo de una Visión de Progreso: CVC 50 años. Cali.

Eder, P. (2001). Colombia. Cali: Manuelita S.A.

Gobernación del Valle del Cauca; Secretaría de Cultura y Turismo. (2007). Historia del transporte y sistema fluvial en el Valle del Cauca. [Multimedia]. Cali: Gobernación del Valle del Cauca.

González de Molina, M. (2009). Sociedad, naturaleza, metabolismo social. En R. Loreto (Ed), Agua, poder urbano y metabolismo social (pp.217-243). Puebla, México: Benemérita Universidad Autónoma de Puebla.

González y González, L. (1999). Pueblo en vilo. México DF: Fondo de Cultura Económica.

Jerez Valderrama, S. E. (2007). Una aproximación a los estudios de las sociedades prehispánicas del siglo XV y XVI en la región geohistórica del alto y medio río Cauca. Cali, Colombia: Universidad del Valle.

Jiménez, N \& Velásquez, A. (2004). La gestión de riesgos en el ordenamiento territorial: inundaciones en Cali, la C. V.C y el fenómeno ENSO. Seminario Internacional Ambiental CVC 50 Años, Cali.

Jiménez, O. (2007). El Frenesí del Vulgo: Fiestas, Juegos y Bailes en la Sociedad Colonial. Premios Nacionales de Cultura Universidad de Antioquia. Medellín: Universidad de Antioquia.

Londoño Motta, J. E. (2010). De «región decimonónica a región nacional»: instituciones, ordenanzas y presupuestos departamentales en la configuración del departamento de Valle, 1910-1948. Segundo Congreso Latinoamericano de Historia Económica (CLADHE-II), Ciudad de México.

Lozano J. (1964). El paisaje que hemos construido. Diario Occidente Año3, No. 868, p. 22.

Marco Macarro, M.J. \& Sánchez Medina, J.A. (2007). Memoria e identidad: una aproximación desde la psicología cultural. En A. del Río Sánchez y J.M. Valcunde del Río (Ed.). La recuperación de la memoria histórica - una perspectiva transversal desde las ciencias sociales, (pp.53-65). Sevilla, España: Centro de Estudios Andaluces.

Mayor Mora, A. (1999). Centenario de un pionero del desarrollo. El ingeniero Francisco Javier Cisneros. 1836 - 1898. Revista Credencial Historia. Edición 102. Publicación digital en la página web de la Biblioteca Luis Ángel Arango. Bogotá, Colombia. Recuperado de http: / / www.banrepcultural. org/node/124744

Mejía Prado, E. (1996). Origen del campesino vallecaucano. Siglo XVIII y XIX. Segunda Edición. Cali: Editorial Universidad del Valle. 
Misión agrícola puertorriqueña. (1930). Reconocimiento agropecuario del Valle del Cauca. San Juan, Puerto Rico.

Montes Giraldo, J.J. (1974). El habla del Chocó: notas breves. Boletín del Instituto Caro y Cuervo. Tomo XXIX: 409 - 428.

Moreno Coronado, A G. (1995). Procesos de poblamiento a orillas del río Cauca el caso de media luna. (Tesis de Licenciatura en Ciencias Sociales) Facultad de Humanidades. Universidad del Valle, Cali.

Muñoz, B. (2005). Modelos Culturales. Teoría Sociopolítica de la Cultura. Barcelona: Anthropos.

Patiño, G. (1989). C.H Simmonds y los Comienzos de la Navegación a Vapor en el Alto Cauca. Boletín Cultural y Bibliográfico, Vol. XXVI.

Plazas y Perry LTDA. (Ed). (1964). Manuelita: una Industria Centenaria: 1864-1964. Bogotá.

Reyes Cárdenas, C \& Montoya Guzmán, J D. (2007). Poblamiento y Movilidad Social en la Historia de Colombia, Siglo XVI-XX. Bogotá: Universidad Nacional de Colombia.

Sturken, M. (1998). The remembering of forgetting: recovered memory and the question of experience. Social Text 57:103-125.

Suárez, Royman. Entrevista del 6 de Febrero de 2010.

Taylor, Ch. (1999). Las Fuentes de la Identidad Moderna. Debats 68, 30-45.

Urrea Giraldo, F \& Murillo Cruz, F. (1999). Dinámica del poblamiento y algunas características de los asentamientos populares con población afrocolombiana en el oriente de cali. En "Desplazados, Migraciones Internas y Reestructuraciones Territoriales, Observatorio Socio-político y Cultural. Bogotá, Colombia.

Valcuende Del Rio, J.M. (2007). Memoria e historia: individuos y sociedad. En A. del Río Sánchez y J.M. Valcunde del Río (Ed.) La Recuperación de la Memoria Histórica - Una Perspectiva Transversal desde las Ciencias Sociales (pp.19-31). Sevilla, España: Centro de Estudios Andaluces.

Valencia Giraldo, V H. (2009). El “yipao”, el atrio y la sábana: medios, modos y espacios alternativos de la comunicación en el Valle del Cauca. Una experiencia desde la salud. Signo y Pensamiento 5:189200.

Valencia Llano, A. (1996). Indios, Encomenderos y Empresarios en elValle del Cauca. Cali: Imprenta Departamental del Valle del Cauca.

Valencia Llano, A. (2004). La Navegación a Vapor por el río Cauca. Cali: Universidad del Valle.

Vásquez Benítez, É., Henao Restrepo, D. y Abella Millán, P. (2001). Historia de Cali en el Siglo 20: Sociedad, Economía, Cultura y Espacio. Cali: Nueva Biblioteca Pedagógica-Universidad del Valle.

Waxer, L. (2000). Hay una discusión en el barrio: el fenómeno de las viejotecas en Cali, Colombia. En Actas del III Congreso Latinoamericano de la Asociación Internacional para el Estudio de la Música Popular, Bogotá, Colombia.

White, H. (1998). Historiography and historiophoty. The American Historical Review 93, pp.1193-1199.

Recibido: mayo 28 / Aprobado: noviembre 25 de 2014 